\title{
Article \\ Social versus Spatial Mobility? Mongolia's Pastoralists in the Educational Development Discourse
}

\author{
Ines Stolpe \\ Mongolian Studies, Bonn University, 53113 Bonn, Germany; E-Mail: istolpe@uni-bonn.de
}

Submitted: 21 June 2015 | Accepted: 12 January 2016 | Published: 15 February 2016

\begin{abstract}
When it comes to education for mobile pastoralists, Mongolia is an exceptional case. Until fifty years ago, herders comprised the majority of the Mongolian population. Although a satellite of the Soviet Union, the Mongolian People's Republic was a state in which mobile pastoralism was not challenged, and herders were not constructed as social outcasts. Equally exceptional was the country's modernisation, witnessed in its decided alignment with equal opportunities. In Mongolia, it was not 'nomadism' that was associated with backwardness, but illiteracy. Policy-makers aimed to combine spatial with social mobility by building schools further and further out in the grasslands, employing locals as teachers, and fostering interplay between modern formal education and extensive animal husbandry. Yet after 1990, when development discourse pigeon-holed post-socialist Mongolia as a Third World country, the so-called shock therapy led to severe cuts in education. Herders were essentialised as 'nomads', which caused donor-driven policies of educational planning to construe pastoralists as challenges. Ironically, during the initial decade of Education for All, the younger generation had-for the first time in Mongolia's history-less educational opportunities than their parents. This article discusses narratives of inclusion and the political consequences of ascribed social identities.
\end{abstract}

\section{Keywords}

development discourse; essentialism; inclusion; nomads; postsocialism; social and spatial mobility

\section{Issue}

This article is part of the issue "Educating Nomadic People", edited by Caroline Dyer (University of Leeds, UK).

(C) 2016 by the author; licensee Cogitatio (Lisbon, Portugal). This article is licensed under a Creative Commons Attribution 4.0 International License (CC BY).

\section{Introduction}

Mongolia ${ }^{1}$ is the least densely populated state in the world (1.8 people per square $\mathrm{km}$ ), and has the largest contiguous common grasslands. Mongolia's herders have experienced drastic changes over the last twentyfive years during the so-called "transition". ${ }^{2}$ Today, half

\footnotetext{
${ }^{1}$ This article focuses on the Mongolian state (self-designated as Mongol U/s), the former Mongolian Peoples' Republic (192492), which is also known as Outer Mongolia. For studies on minority education in the Inner Mongolia Autonomous Region in PR China, see Leibold and Yangbin (2014).

${ }^{2}$ Former socialist countries, which used to belong to the socalled 'Second World', were classified as 'transition countries' in 1990 under the assumption that they would perform their "transition to a new order" (Innes-Brown, 2001, p. 77) by following Western ideas. The "prescribed pillars of transition"
}

of Mongolia's three million inhabitants cluster in the capital Ulaanbaatar; around 30\% live in rural areas. Rural-urban migration was prompted largely by the neglect of rural areas, consecutive economic crises, and environmental degradation, but also by climate change and the mining boom. Although the country maintained high levels of education, the demographic changes caused by massive rural-to-urban migration led to alarming disparities between Mongolia's few urban centres and its rural areas. $47.8 \%$ of the rural population are now considered below the poverty line, and poor households show a high rate $(20.5 \%)$ of having either no education or only a primary education. Agriculture, including herding, accounts for $18.1-23 \%$ of

(Kerven, 2003, p. 16) were privatisation, deregulation, and withdrawal of the state. 
Mongolia's GDP and provides work for $34-38.5 \%$ of the country's labour force. $92 \%$ of countryside inhabitants own livestock, as do $54 \%$ of county-centre residents and $17 \%$ of province-centre dwellers. The number of livestock, which had remained relatively stable between 22-25 million animals for fifty years, has nearly doubled since 1990-the number of cashmere goats has even quadrupled-at the cost of pasture degradation (United Nations Development Programme \& Government of Mongolia, 2011, pp. 33-47).

Before the political changes of 1990, mobile herders were not characterized as 'nomads', and they were neither marginalised, nor educationally deprived. This article shows how the recent discursive 'nomadisation' of herders contributed to a dispossession of their previously well-respected status. In Mongolia, narratives of 'inclusion' are inseparably linked to constructions of social stratification, which in turn have been constituted by development discourses (Stolpe, 2008).

Hardly any state is so heavily associated with nomadism as Mongolia. Mongolians are portrayed as 'nomads' par excellence-whether in movies, picture books, photo exhibitions or at the International Tourism Fair, where Mongolia was featured as the official partner country with the slogan Nomadic by Nature in spring 2015. Yet those who live as mobile pastoralists have never labelled themselves 'nomads'. Until the mid-twentieth century, the majority of the Mongolian population was engaged in extensive pastoralism. Thus, as the norm, the mobile way of life did not require any contrastive terminology. Nowadays, the academic world widely agrees that "Nomadism is a category imagined by outsiders" (Humphrey \& Sneath, 1999, p. 1), an external ascription of difference. Mongolian academics have criticised the emerging boom of a discursive 'nomadisation' as ingratiation with external perceptions. Dorjgotov (2002, p. 109) pointed out, "If we call ourselves nomadic people it will mean that we are simply a homeless tribe or people having no permanent abode. What kind of people will we be after all?" The quote indicates that the new nomad-image appears alien because it is implicitly associated with backwardness. Moreover, as Myadar (2011, p. 335) noted, the image serves "the habit of outsiders to construct an imagined Other and the need of Mongolians for cultural demarcation".

When today's urban Mongolians present their state as a 'country of nomads', they take up a common-and profitable-stereotype. Whether in tourism, research environments, development policy, or with regard to postmodern lifestyles, fascination with 'nomadism' is undiminished. More often than not, the ascription of this collective identity is associated with quite abstruse "myths of the nomad" (Khazanov, 1984/1994, p. 1), which derive their attraction from the binary opposition nomadic-sedentary. Not without reason, Chakrabarty (2000, p. 6) stated that European catego- ries are "both indispensible and inadequate". In Mongolia, the stylisation as a 'country of nomads' is exclusively present in cosmopolitan settings, which indicates the political dimensions of cultural representation. Clammer (2003, p. 21) characterised the process of "mapping the Self with the categories of the Other" as "intellectual colonialism." When examining terminological change, I follow Clammer's suggestion to use a methodology "that might move beyond the temptations of either Orientalism or Occidentalism", particularly with regard to two aspects:

First, recognition of the extent to which local readings of Asian societies using the disciplinary frameworks of Western academic subjects with their built-in epistemological biases is at the basis of selfmisrepresentations, as much as it is the source of Orientalist misrepresentations. Second, paying serious attention to indigenous social theory and refusing the temptation to dismiss it as 'nativist'. (2003, pp. 28-29)

The Mongolian case features an additional dimension: before and after the Cold War, two contrary development paradigms determined the designation of herders, which reflected a change in the political frame of reference and entailed a shift in the external audience addressed. Mongolian categories remained largely untouched by these changes (but also largely ignored). Today's one-sided adaptation to hegemonic categories of the West may be motivated by strategic and/or pragmatic reasons; however, its associated homogenisation inevitably obscures distinctive cultural features. In order to shed light on the interplay of selfperception and ascribed attributes as well as their implications for the development discourse, let me start by giving a brief historical account of canonised narratives on Mongolian herders. ${ }^{3}$

\section{Shifting Paradigms - Inclusive and Exclusive Terms of Reference}

Those who engage in extensive animal husbandry have never called themselves 'nomads'; instead, their endonym has always been malchid, ${ }^{4}$ a de-nominal derivation from mal (i.e. Mongolian livestock: horses, sheep, cattle, goats, and camels). The oldest surviving literary historiography, the Secret History of the Mongols, provides information on a self-designation as "people with

\footnotetext{
3 For a complementary analysis of Mongolian educational terms, see Stolpe (2010).

${ }^{4}$ The spelling of modern Mongolian words follows the established convention widely accepted in English-language literature. Terms in quotations and names in references remain in their original form. Unless otherwise indicated, all materials appear in the author's translation.
} 
felt-wall dwellings" (Taube, 2005, p. 139)-a medieval version of defining an ethnoscape (Appadurai, 1996) via this particular kind of mobile housing (commonly yurt, in Mongolian ger).

Since the 1990s, Mongolia-related English publications have used the term 'nomads' only reluctantly; instead, they have preferred 'herders', 'pastoralists' or 'herdsmen' (Fernández-Giménez \& Huntsinger, 1999; Ginsburg, 1997; Mearns, 1993a, 1993b; Schmidt, 1995; Sneath, 1996, 1999, 2000; Szynkiewicz, 1998). This reluctance to use the term 'nomadism' mirrors an awareness that has arisen from the orientalism debates. While we hardly find 'nomadism' in the writings themselves, the term features prominently in book titles (Ginat \& Khazanov, 1998; Humphrey \& Sneath, 1999; Krätli, 2000 Stolpe, 2008; Tavakolian, 2003). Publications that have been translated from Mongolian into English also use the terms 'herders' or 'breeders', as they come closest to the original malchid (cf. Gundsambuu, 2002; Namkhainyambuu, 2000; Natsagdorj, 1967). In contrast to malchid, which dominates Mongolian discourses, nüüdelchid-the equivalent for 'nomads' - has been used primarily in historical accounts that deal with the emergence of human life in Central Asia (Ganbaatar, 2001; Lkhagva, 2003; Tömörjav, 1989; Tsanjid, 2005). Exceptions are publications by the International Institute for the Study of Nomadic Civilisations, where Mongolian authors have adapted their wording to fit the 'nomadism' programme (cf. Avdai et al., 2003; Enebish, 2002; Sum'yaa, 2005; Tömörjav, 2002). This terminological change towards 'nomads' and 'nomadism' applies all the more for English publications by Mongolian scholars (Enebish, 2004; Enkhtuvshin, 2002, 2004; Enkhtuvshin \& Tumurjav, 2001). Although such terms were hardly used by Mongolian scholars prior to the end of the 1990s, they are currently booming. Apart from obvious pragmatic reasons, including a seemingly convenient translatability, the term 'nomad' provides considerable advantages in the struggle to gain attention-whether in tourism, pop culture, research proposals, or development projects. In this way, Mongolian 'nomads' are an invention of post-socialism.

During socialism, in all texts that were directed at an external audience, the discursive space that is today occupied by 'nomad' was the domain of arat. Within the socialist camp, this conception had evolved to become the established term for designating Mongolian herders, while it remained largely unknown on the other side of the Iron Curtain. Before the Mongolian revolution, arat was used to describe a certain group of herders through reference to property and ownership relations (cf. Natsagdorj, 1967). Sneath (2003) noted that, when the Mongolian Peoples' Republic was founded in 1924, no equivalent for the term 'people' existed. Since arat (correct in Mongolian: arad/ard) means 'common people/commoner', it came closest to the understanding of 'people' as intended in accord- ance with Marxist class theory. Given that Mongolia had neither a proletariat nor peasants, arat became their functional equivalent. Accordingly, the constitution of 1940 stated that the Mongolian Peoples' Republic was an independent state of working people, arat-herders, workers, and intelligentsia. Soon after, the notion of arat underwent another transformation: from class categorization to professional designation. Regardless of whether they had a formal education, herders were ascribed the status of well-respected professionals, and their societal acknowledgment was undoubted.

When comparing the disparate impact of the two terms used to address a foreign audience (the selfdesignation malchid has remained), the term arat has clearly created a positive collective identity. Ideologically-ridden or not, associating herders with 'the people' and equating their work with every other profession enabled arats to actively take part in modernization. Consequently, they were considered mainstream, and hence portrayed neither as exceptional nor as marginalised. In addition to its professional status, pastoralism was esteemed as a primary source of valuable indigenous knowledge-including on the philosophy of education-in countless Mongolian publications issued during socialism (Dash, 1966; Shagdarsüren, 1969; Sükhee, 1988; Tömörjav, 1989; retrospective: Chagdaa, 2002; Shagdar, 2000). In contrast, the post-socialist construction of the term 'nomad' came as an act of othering and caused pastoralists to be characterized as a challenge by donor-driven development policies. As will be shown below, the political dimension of social identities strongly influenced how "societies stratify and divide...and how the processes that include and exclude are talked about, described, understood, and experienced" (Allman, 2013, p. 6).

Pastoralism and education policy in the Mongolian People's Republic were once closely interconnected, aiming at combining spatial with social mobility. Yet, donor agencies, which dominated the formulation of Mongolian education policies after the end of socialism, denied this unique combination when they equated Mongolia with 'developing countries'. The term arat was replaced by 'nomad' at the same time Mongolia was downgraded from a Second World to a Third World country. These changing representations did not remain at a discursive level, but structured political action guided by a development paradigm, which did not favour social inclusion. Furthermore, there was a widespread tendency to condemn everything associated with socialism for ideological reasons and to simply equate Mongolia with the Soviet Union; in an orthodox narrative, nomadism and socialism are considered antipodes with the latter attempting to abolish the first by means of settlement. Such black-and-white thinking usually ignores two aspects: first, nomadism had been considered an outdated, inefficient way of life and an 
obstacle to modernization on either side of the Iron Curtain (cf. Dyer, 2001; Fratkin, 1997; Galaty \& Johnson, 1990; Krätli, 2000). Second, forced settlement is, more often than not (especially under post-socialist conditions), connected to privatisation, poverty, and land grabbing. Throughout post-socialist Central Asia, pastoralists' mobility decreased after 1990 (cf. Kerven, 2003), and Mongolia is no exception to this trend.

However, the country used to be exceptional: although the Mongolian Peoples' Republic was strongly influenced by its 'elder brother to the North' (khoid $a k h)$, nomadism policy was one of the spheres in which the satellite kept a considerable distance from its leading star. Unlike pastoralists in Soviet Central Asia, herders in the MPR were spared settlement programmes since pastoralism was acknowledged as the key branch of Mongolia's agriculture. Another area in which the MPR kept its distance from Soviet policy was collectivisation. While it was pushed through violently in the Soviet Republics, the first attempt in the MPR was cancelled because of uprisings. The second attempt was not made until thirty years later and resulted in the desired success due to incentive-based procedures and improvements in overall conditions (cf. Finke, 2000, 2004; Humphrey \& Sneath, 1999; Szynkiewicz, 1998; Tömörjav, 2002). Consequently, "Pastoralism did not experience any economic, political or ideological marginalisation in Mongolia because its importance in economic respects and its being a fundamental feature of traditional Mongolian culture was generally acknowledged" (Finke, 2004, p. 398).

The collectivisation of livestock was complemented by services provided through modern institutions like schools, hospitals, post-offices, veterinary stations, shops, cultural centres, and libraries. The presence of rural centres is sometimes interpreted as an indicator of settlement policy, although, as comparative studies have shown, the mere existence of immobile infrastructures does not imply decreasing spatial mobility (Humphrey \& Sneath, 1999). There is a broad consensus that the successful combination of mobile and sedentary lifestyles in the course of modernisation led to mutual integration, which Mongolian scholars capture in a nutshell with the phrase neg uls, khoyor irgenshil"one state, two civilisations" (Bira, 1998/1999; Chagdaa, 2002; Chuluunbaatar, 2002; Gundsambuu, 2002). This wording is by no means coincidental since civilisation is associated with modernity and progress. Both are unthinkable without social mobility. It is fair to say that the Mongolian Peoples' Republic was probably the only state with a "nomad-mainstreaming" (Stolpe, 2015, p. 28) strategy, since MPR state policy-as well as institutions-aimed to promote equal opportunities. By the end of the 1960s, the MPR was the first state in Asia to achieve general literacy through universal basic education; for its success, the MPR was awarded a UNESCO medal in 1970 (Dorzhsuren, 1981, p. 109;
Sandhaasüren \& Shernossek, 1981, p. 12). In discussing equal opportunities, another unique feature should be mentioned: the inverse gender gap. Since gender balance was reached in the 1970s, Mongolian educational institutions have had a higher proportion of female graduates. By the end of socialism, Mongolia had a literacy rate of $96.5 \%$ (Mongol Ulsyn Zasgyn Gazar \& UNDP, 1997, p. 7). Thus, a country shaped by mobile animal husbandry had "a higher literacy rate than the United Kingdom or the United States, and a higher tertiary education rate than most countries in the developed world" (“Call for increased focus on education", 1997, p. 7).

All this could be achieved because of the close connection between education policy and animal husbandry-particularly witnessed in school organisation-and because of the permeability of Mongolia's educational system, which encouraged upward mobility for pastoralists. In brief, the following factors contributed to the mutual integration of education and nomadism. The universal right to free education was part of the first constitution of the MPR, issued in 1924. Consequently, secular primary schools implemented the modern and socially inclusive principal of co-education. Mobile teachers offered literacy training for youth and adults. The first boarding schools in the grassland appeared during the 1930s, and were-at first-mostly situated in gers. Unlike the USA (Child, 1998; Connell Szasz, 1974/1999) and the USSR (Bloch, 2003), Mongolia's boarding schools did not encourage assimilation to a sedentary lifestyle, de-skilling (Dyer, 2001; Krätli, 2000), or cultural alienation. In fact, they continued a pre-socialist model of access to formal education for children from herder families. Prior to the revolution, monastic schools throughout the country had offered formal education for boys. From the 1930s, anti-religious laws prohibited enrollment in monastic schools; yet by the time the first state-run boarding schools were established, the model of lodging in the nearest educational institution had already been mainstream in the steppe for a long time. They attempted to provide a familyoriented atmosphere, allowing siblings and/or neighbours (boys and girls alike) to share a ger, or, later, a room (Steiner-Khamsi \& Stolpe, 2006). In 1943, schools for young herders were established in the countryside, and women were particularly encouraged to gain formal education. Nearly all teachers had a background in pastoralism, and most of them were locals. By the end of the 1940s, all provinces (aimag) and a few counties (sum $)^{5}$ had a secondary school. In Mongolia, it was not 'nomadism' that was associated with backwardness, but illiteracy, which the official historiographical narrative represented as the heritage of feudalism

\footnotetext{
5 There were several administrative reforms during socialism. While the number of aimag (18) was stable for decades, the number of sum fluctuated around 300 . Today, Mongolia is divided into 21 aimag, 331 sum, and 1,550 bag.
} 
(Dorzhsuren, 1981, p. 109; Sanzhasuren, 1981, p. 89).

Compulsory school attendance for all children was fully implemented only in the school year 1955/56, when the herder collectives (negdel) helped build schools with dormitories further and further out in the steppe. With collectivisation came social security for herders and a reduction in workload due to specialisation. Nevertheless, labour was always scarce, which informed the annual school schedule's coordination around peak-periods in animal husbandry. Together with late school entry (at age 8 ) and long vacations, this coordination ensured that schoolchildren were continuously socialised into pastoralism, which encouraged situated learning (Lave \& Wenger, 1991) in mobile animal husbandry. Moreover, polytechnical classes were now and again held by members of herder collectives, and university students were periodically sent to the countryside to help during labour peaks. Most Mongolian state institutions, including educational institutions, had their own herds. ${ }^{6}$ Those who tended the school herds (surguuliin malchid) were members of the school collective; they appeared beside teachers, nurses, cooks, and janitors in wall newspapers or booklets that introduced school staff. The most considerable expansion and internal differentiation of the educational system began after 1962, when the MPR became a full member of the Council for Mutual Economic Assistance (COMECON/CMEA) and began receiving a higher amount of external funding to extend and maintain its boarding school system. By the 1970s, almost every county (sum) had a secondary school with a dormitory. Further, many herder collectives built primary schools in even the smallest administrative subunits $(b a g)$ that were closest to the pastures.

Most teachers shared their students' background, which explains why, to this very day, Mongolian schools are very flexible in adjusting to the needs of those who practice animal husbandry. For example, if weather conditions require herders to graze their animals on remote pastures, teachers tolerate students' late appearance at the beginning of the new school year. During times of hardship like zud, ${ }^{7}$ rural schools still organise help for herders, as they did during socialism. Under socialism, schools introduced the so-called 'summer task' (zuny

\footnotetext{
${ }^{6}$ For rural schools, it is still an advantage to own a herd and thus be able to provide dormitory students and teachers with meat supplies.

${ }^{7}$ Zud: times of hardship during the winter/spring season. From the perspective of Mongolian herders, zud is the effect, not the cause, contrary to the widespread Eurocentric representation of zud as a 'high snow' or 'cold spell', neither of which necessarily leads to a disastrous mass mortality of livestock. The Mongolian standard idiom gan zud shows that drought (gan) usually precedes zud. The complexity of causes and effects is reflected in sub-categories of zud. Political and structural conditions significantly influence whether or not weather conditions result in a disastrous loss of herds (Stolpe, 2011).
}

daalgavar), which required students to explore features of the local geography and prepare concentrated forage (i.e. allium pellets) as part of zud-prevention. During the post-socialist crisis of the 1990s, the summer task was distorted: since rural schools suffered from a lack of state support, children were expected to collect dried dung for heating, as well as bring meat and dried curd as contributions to the suddenly scarce food provisions in dormitories. With the recent commercialisation of horseracing, it has become customary for schools to allow students to take extra vacations to train racehorses in the steppe; nowadays, poor families who live in urban areas (especially in the highly polluted capital Ulaanbaatar) consider racehorse training a welcome opportunity to send their children to the countryside for healthier food and fresh air. ${ }^{8}$ These examples may illustrate against what background Krätli, who did a comparative study on education provision to nomadic pastoralists, identified as a remarkable "non antagonistic culture towards nomadism" (Krätli, 2000, p. 48) during his on-site research in Mongolia. All schools were part of the same education system, and pastoralists were not segregated. Namkhainyambuu remembered:

In 1971, I was a youth representative in Ulaanbaatar, and I participated in the Fourth MongolianSoviet Games. At that time I understood that there is nothing a young man can't do and can't learn. I also discovered how the young boast of their vigour and hard work, as well as realising that the profession of herder was well respected. In 1972, the labour youth representatives from one hundred and twenty nations held a meeting in Moscow....Thus because of my herds, I was able to travel abroad and see the world. (Namkhainyambuu, 2000, p. 53)

An even more prominent example of (even extraterrestrial) upward mobility is Mongolia's one and only cosmonaut J. Gurragchaa, likely the only spaceman worldwide who comes from a pastoralist family. Gurragchaa's parents followed their son's 1981 space flight by listening to a live broadcast from a battery radio in their ger, out in the steppe (Ontsgoi tomilolt, 2001).

Against this backdrop, it is evident why the postsocialist downgrade from the Second to the Third World was shocking, even more so since the Human Development Index data did not correspond to this category. But in the face of the severe economic crisis that followed the collapse of the COMECON, Mongolia's government had to make concessions to international donors to receive loans. While most accounts written by foreigners tend to praise the initial years of democratisation as liberation, paving the way to free-

\footnotetext{
8 Personal communication and exchange of letters with teachers of rural and urban schools, as well as with students and parents (2003-2015).
} 
dom, Mongolian citizens (even in retrospect) hardly describe the early years of post-socialism as times of upswing. Especially in rural areas, the so-called transition was perceived as a regression, as "having lost decades of improvement with conditions beginning to resemble those of the 1940s!" (Sneath, 2002, p. 196). What had happened? Reforms in the agricultural sector started in 1991-93 with de-collectivisation, which was generally well-received. Many herder families took their children, especially boys, out of school in order to cope with the workload that came with multi-species herds, and the inverse gender gap widened in the 1990s: by 1997, $16.7 \%$ more girls had entered secondary school in rural areas than boys (Yembuu, 2008, p. 28). After the privatisation of 26 million heads of livestock, animal husbandry was the only economic sector with good growth rates. But the withdrawal of the state resulted in the collapse of rural infrastructure, including essential social services. This led, in combination with unemployment and the disastrous supply situation, to a retreat into rural subsistence economy. The 95,000 so-called new nomads (Mongol Ulsyn Zasgyn Gazar \& UNDP, 1997, p. 17) were mostly former state employees who tried to make ends meet with "pre-modern means of subsistence" (Bruun, 1996, p. 65). By the end of the 1990s, this apparent conversion to 'nomadism' had shifted into a massive rural-tourban migration of more than half a million people, thus turning the so-called nomads into a minority.

Rural areas have been disadvantaged since 1990, especially in service provision. At present, $68 \%$ of Mongolia's three million people live in urban areas, most of which have settled in Ulaanbaatar (United Nations Development Programme in Mongolia, 2014). In the coldest capital of the world, which has recently gained sad notoriety for peak amounts of air pollution, two thirds of the population live in ger districts with insufficient infrastructure. Reasons for rural-to-urban migration are manifold, but the hope for social mobility-i.e. for better educational opportunities-ranks, after economic reasons, second. This is due to the fact that, after the political changes, the younger generation who lived in the countryside had poorer educational opportunities than their parents' generation had had. In contrast to other parts of the world (for Tibet see Postiglione, Jiao, Xiaoliang, \& Tsamla, 2014), where pastoralists never had proper access to formal education, there was no need to popularise formal education in Mongolia. On the contrary, herders actively defended their right to equal educational access in order to remain an integral part of modern society.

\subsection{Herders in the Blind Spot of Educational Development}

The present unequal access to quality education in Mongolia is, for the most part, a result of the educa- tional reform undertaken in the 1990s. The first Masterplan, prepared in 1993, proposed for rural areas low-budget schools with multi-class teaching, mobile teachers, and even ger schools. Under Qing rule, ger schools (geriin surguul') were established to qualify clerks (khia) for menial tasks (Baasanjav, 1999, p. 325; Rinchen, 1964, pp. 30-33; Shagdar, 2000, p. 70; Shagdarsüren, 1976, p. 26). In the earliest years of socialism, ger schools were considered a makeshift solution because, in contrast to modern school buildings, they could not provide facilities for modern, scienceoriented teaching. Hence, the rural population, including herders, who had been used to equal opportunities, did not approve of these discriminatory suggestions made by the Master Plan. While some foreign consultants considered it a good idea to link the present with pre-socialist times, even after more than seventy years, herders resisted school models, which they considered relics of a bygone past. Yet, the new dominant ideology implied that schools would be an "instrument of sedentarization", that "boarding schools introduce children to the sedentary lifestyle" (Postiglione et al., 2014, p. 108), and that "modern school education is not embraced by local people" (Postiglione et al., 2014, p. 118). In Mongolia, the opposite had been the case. Yet even the most successful features of the educational system had to give way to a neoliberal ideology that treated history as reversible, as though socialism "only existed outside the 'correct flow of history'", and as if countries could return to a "status quo ante" (Giordano \& Kostova, 2002, p. 78), which was imagined as their 'true' self. Disillusioned statements like the following have been heard in Mongolia ever since: "Foreign consultants tend to come in with answers before they know the questions-these are answers they have produced in other countries and they don't really have the time to develop the true needs for Mongolia" ("Call for increased focus on education", 1997, p. 7).

In this context, Mongolian pastoralists were suddenly ascribed all kinds of vaguely 'nomadic' interests that, more often than not, ignored the target group's views. Herders saw mobile teachers, ${ }^{9}$ ger schools, and multi-class instruction as second-class education that provided students with poor qualifications. Reducing people to being 'nomads' proved to be an essentialisiation of spatial mobility and demonstrated ignorance of the fact that modern social mobility is based, worldwide, on the social capital of formal education: as Dyer and Choksi found during their fieldwork among Indian pastoralists in Gujarat, the Rabari expected formal education to provide added value, and considered it an important means of emancipation (Dyer \& Choksi, 1998).

Some proposals of the first Masterplan were a con-

${ }^{9} \mathrm{~A}$ much promoted mobile teacher project initiated by UNICEF was terminated in 1998; no replacement was provided. 
sequence of downgrading Mongolia to the so-called Third World. As a result, the country was subjected to neoliberal education policies in a similar manner as sub-Saharan Africa (UNESCO, 1993), which had even been dealt with as a single entity (Samoff, 1999). The "discursive homogenization" (Escobar, 1997, p. 92) of the so-called developing world allowed 'developing' countries hardly any control, let alone ownership. They lost control to foreign consultants who displayed a been-there-done-that attitude and came up with a prefabricated canon of recommendations. Accordingly, former Education Secretary Tsanjid criticised the rigid policies of international donor agencies as "Westernising" (örnödchlökh) or "Americanising" (amerikchlakh) approaches, which seemed all the more bitter to Mongolians in light of their hope that ideological constraints would disappear with the end of socialism (Tsanjid, 2005). Regarding education for pastoralists, the status loss from Second to Third World became a self-fulfilling prophecy: simultaneously with what is usually called 'transition to democracy', children from nomadic families encountered significant structural discrimination for the first time in Mongolian history. Decreasing school attendance in the 1990s led to a statistically relevant recurrence of illiteracy-ironically synchronous with the first Education for All decade. ${ }^{10}$

Boarding schools, although undoubtedly key to ensuring universal access to education in Mongolia, turned into the most contested subject of educational reforms. Under the structural adjustment programme, the Mongolian government was pressured to reduce public spending on education and forced to cut its budget in half (World Bank, 2002). Small and boarding schools were now considered not cost-effective; some were shut down. Since the early 1990s, Mongolian government representatives desperately tried to garner support to save dormitories, but their requests fell on deaf ears. Even a specially prepared application for the 2001 donor conference in Paris was rejected. Since no Western models could have been imported into the Mongolian education system, boarding schools fell from grace for obviously ideological reasons: donors refused to retain a model that was associated with the socialist past, no matter its inclusivity. Thus, the main vehicle for education fell victim to a transfer vacuum. One noteworthy exception to this ideologically biased neoliberal policy was the Rural School Development Project, funded by DANIDA ${ }^{11}$ and managed jointly by the Mongolian Association of Primary and Secondary School Development (MAPSSD) and the Mongolian State University of Education. The Rural School Devel-

10 In 1990, Mongolia subscribed to the World Declaration on Education for All.

${ }^{11}$ DANIDA is the term used for Denmark's development cooperation, which falls under the Ministry of Foreign Affairs of Denmark. opment Project operated from 2000-2010, and engaged 80 remote boarding schools across Mongolia by using a community-based approach to enhance the quality of and access to education. At a time when rural Mongolia had been widely ignored by all major donors, the project helped communities improve boarding school facilities and develop strategies to foster social inclusion of children from herder and poor families.

The post-socialist crisis of Mongolia's educational system found its most spectacular expression in soaring drop-out rates, which reached a peak in 1992/93, when 48,446 students left school (Mongol Ulsyn Zasgyn Gazar \& UNDP, 1997, p. 25). Most dramatic was the situation in rural areas, where nine out of one hundred children between ages 8 and 10 did not attend school. For youth between ages 11 and 17, drop-out rates reached 50\% in 1996 (Batjargal, 1997, pp. 43-44). These unintended side-effects of the 'transition' became a hot issue of public debates. A much noted article was published in the national newspaper Zuuny Medee under the headline, "Among us are 200,000 adolescents who are illiterate" (Düger, 1999, p. 3). Sociologist Gundsambuu also expressed his concern about an emerging social inequality, and called the rising numbers of "uneducated or sub-educated youth and children" among herders "the main cattle-breeding feature of Mongolia" (Gundsambuu, 2002, p. 22). The 1997-Mongolian edition of the Human Development Report predicted that the low educational standard would be felt for the next 70 years (Mongol Ulsyn Zasgyn Gazar \& UNDP, 1997, pp. 25-26). "70 years" clearly alludes to the success of accomplished literacy during the socialist era.

Interestingly, many studies located the problem's origin exclusively outside educational policy. The official Education for All report-which was published under the promising title Mongolian National Report on Education for All Assessment-2000, but was oddly based on a case study from 1996-provides the most striking example. The gross enrolment ratio showed a difference of more than $20 \%$ between enrolment in rural and urban areas, yet the report provided no analysis of this phenomenon, nor of the decrease in students who lived in dormitories, which dropped from $14.5 \%$ in 1990 to $4.1 \%$ in 1996 . The study was compiled under the aegis of the government that was responsible for introducing the requirement that herder families provide foodstuffs in order to have their children accommodated in dormitories from 1996. ${ }^{12}$ Through this requirement, mobile pastoralists became the only social group in Mongolia to pay for access to primary and secondary education, a payment that contravened article 16 of the 1992 Constitution, which declares the

\footnotetext{
12 The policy requested $70 \mathrm{~kg}$ of meat per child each school year. Poor families, especially those with more than one child in school, could not afford to slaughter animals.
} 
right to basic education free of charge. ${ }^{13}$ After 1996, poorer herder households could not afford to send their children to boarding schools until 2000, when these hidden fees were cancelled by decree of the new government, and forbidden by educational law in 2002. Most startling for a study called an "assessment" and done under the auspices of UNDP, UNESCO, UNICEF, UNFPA, and World Bank is, in addition to being based on outdated data from 1996, the reliance on a sample of merely 108 interviewees, only four of which were in Ulaanbaatar. Among the five reasons the report listed for dropping out of school, all but one located the problem on the side of the students and their families. Particularly striking is the report's use of the blaming category "lack of interest in learning" (Munkhjargal, 1999, p. 43), which was introduced in Mongolian discourses in the 1990s, and still persists in modern statistics despite the fact that the category has never been explained. ${ }^{14}$

Finally, the decentralization policy had unintended consequences for the access to and quality of education. The policy was based on the unproven assumption that decentralised decision making would automatically lead to better management. Alas, quite the contrary occurred: responsibilities were ill-defined, there was a lack of communication, planning did not have much effect in an environment of uncertainties, and school principals were expected to raise funds at a time when there was hardly any cash available in rural areas. ${ }^{15}$ Paradoxically, since only larger schools in aimag centres received support from the Asian Development Bank, Mongolia's once-decentralised net of boarding schools became more centralized. Consequently, education-minded pastoralists were forced to either settle in provincial centres or separate their families (SteinerKhamsi, Stolpe, \& Tümendelger, 2003; Stolpe, 2008).

\section{Discussion}

In 2013, Mongolia ranked $103^{\text {rd }}$ in the inequalityadjusted Human Development Index (a fall from its 2010 rank of 100) with Turkmenistan and the Maldives, following after the Dominican Republic (102), and Samoa and Palestine. ${ }^{16}$ Not without reason does the latest Human Development Report highlight Mongolia's issues with sustainability and recommend that citizens be given opportunities to exercise freedom of partici-

\footnotetext{
${ }^{13}$ Since the amount of meat had to be delivered before one's child could be enrolled, this was considered a hidden fee (dald tölbör) by herder families who depended on the boarding school system.

${ }^{14}$ For a recent example, see: http://www.meds.gov.mn/data/ 1503/BDB14-15.pdf. The habit of collecting data without properly analysing them has been criticised by Mongolian educationalists since the late 1990s (cf. Monkhor \& Damdinsüren, 1998). 15 For comparable experiences in other parts of the world in the 1990s, cf. McGinn and Borden (1995) and Tatto (1999). ${ }^{16}$ http://hdr.undp.org/en/search/node/hdi\%20mongolia
}

pation, including the freedom to learn (United Nations Development Programme \& Government of Mongolia, 2011 , pp. 13, 35). Low turnouts in the last parliamentary election give cause for concern, particularly as processes of social exclusion are driving forces of postdemocratic tendencies. Without doubt, poverty is the main contributor to social exclusion. Many children in Mongolia grow up under precarious circumstances and experience marginalisation on a daily basis. Comparative studies (Solga, 2014) suggest that investment in education be combined with high standards of social protection in order to enable as many people as possible to achieve the highest possible level of education. Although Mongolia's education policy makers are busy overcoming negative consequences of the so-called shock therapy that led to a disadvantage of pastoralists, the country's new urban-centrism is a strong counterforce. Even stronger is middle class centrism, which creates a lack of solidarity. Before I briefly return to this aspect, let me give some examples of the struggle to compensate for the shortcomings of non-inclusive policies.

It took more than a decade and a half to rehabilitate school dormitories. The current Education Masterplan (2006-2015), in accordance with the Dakar framework for action: Education for all, aims at "reduction of social inequality and disparities through undertaking strategic actions to make educational services accessible and inclusive at all territorial levels", and aims "to expand further opportunities of rural people and social [sic] vulnerable groups to obtain education" (Government of Mongolia, 2006, p. ix). Herder's children's access is to be improved by increasing accommodation in dormitories by $40.5 \%$, and is designed to finally reach $75 \%$. Drop-outs are to be returned to schools, or provided with non-formal education (Government of Mongolia, 2006, p. xiii). In order to get an impression of recent developments, it may be useful to review some statistical figures. In 2008/2009, a total of 492 boarding schools hosted about $8.4 \%$ of the overall student population. Out of the 42,064 students enrolled, 36,786 came from herder families. In 2009, 57\% of all countryside schools ${ }^{17}$ were located in sum centres, and $6 \%$ in bag-centres. Sum schools accommodated $20 \%$ of their students in dormitories; bagschools accommodated more than 50\% (UNESCO, 2011; Asian Development Bank, 2013, pp. 10ff). According to current statistics provided by the Mongolian Ministry of Education, out of the 762 schools in Mongolia, 552 are rural schools. At present (school year 2014/15), there are 486 dormitories, 12 of them privately owned. Of the 505,816 students enrolled in school, 109,599 are children from herder families ( $\mathrm{mal}$ chdyn khü̈̈khed), 32,858 (30\%) of which live in dormitories (Ministry of Education, Culture and Science,

17 Mongolian education statistics usually count provincial (aimag) centres under the category "countryside". 
2015). These figures make the Masterplan's ambitious goal to house $75 \%$ of herder children by the end of 2015 decidedly unlikely.

While the current Masterplan acknowledges the significance of dormitories, some ADB consultants still fail to recognize their importance, as the following example shows. As part of the Asian Development Bank's Financial Crisis Response Project, studies were completed under the headline "Education for the Poor" in 2013 (ADB, 2013). The suggestions put forward for revision concern per student financing, school uniform cost reduction, and the kindergarten free meal programme. Per student financing, introduced in 1998, contributed to a chronic underfunding of rural schools, who received less and less funding as a result of ruralto-urban migration. Representatives and advocates of remote schools objected to this funding scheme, which led to countless corrections of the funding formula. Yet, with the suggestions made in the ADB-paper, dormitories fell into disgrace once more: "This is an added cost, unrelated to a school's primary purpose-student learning" (ADB, 2013, p. 18). The paper suggested that funding for dormitories be slashed by $90 \%$; ironically, a footnote indicates that the authors of the study did not know the amount then spent on dormitories. ${ }^{18}$ Interestingly, the Mongolian version of the study does not read "Education for the Poor", but instead reads, "Making education accessible for citizens of socially vulnerable groups" (Niigmiin emzeg bülgiin irgeded bolovsrolyn ülchilgeeg khürgekh ni), thereby using more politically correct language.

Since 1997, "Gegeerel (Enlightenment) Centres" existed in every district and sum, and were expected to provide literacy programmes for out-of-school children and youth. In 2001, the Ministry of Education started equivalency programmes, which complied with $75 \%$ of formal education standards (Yembuu, 2008). The programmes were meant to provide equivalent knowledge for all levels of education and "eradicate illiteracy" (Yembuu, 2008, p. 10). The newly amended Education Law of 2006 aimed to serve people outside the formal education system. However, non-formal education often deprives children of quality teaching. Those in charge tend to offer short-term courses on what is called 'livelihood training'-a potpourri of 'life skills' that are often not in demand by the target group. At present (school year 2014/15), 10,067 students-of which 6,895 are boys-participate in the programme (düitsen khötölbör) (Ministry of Education, Culture and Science, 2015). The higher percentage of boys in the programme reflects the aftermath of the privatisation of livestock in the 1990s, when many herder families took boys out of school. Since a great number of pastoralists lost their herds during the consecutive zud disasters around the turn of the century, many of their now grown-up boys, lacking for-

18 Peter R. Moock and Batchimeg Namsraidorj (2013). mal education, struggle to find a job. ${ }^{19}$

Statistical figures on drop-outs and out-of-school children are usually rather whitewashed, as they exclude those who participated in short-term courses of non-formal education. Figures currently report 94 drop-out/out-of-school children in Ulaanbaatar, and 1075 in the countryside. Of these children, 367 state poverty (amidralyn gachigdal) as the reason for their absence from school, but most (527) are reportedly out of school for health reasons. Figures are proportionally higher in the countryside, and the same applies for children not-yet enrolled (669 out of 726) (Ministry of Education, Culture and Science, 2015). Hence, it is difficult to avoid the impression that this disproportionality was caused by the lowering of admission age from eight to seven in 2005 and from seven to six in 2008. Pastoralist families are clearly disadvantaged by these measures, which favour urbanites who live close to schools. As a consequence, children who live in the countryside drop out more often, or enroll later, two patterns that may bar the children from formal schooling if the family migrates to Ulaanbaatar, where formal schools refuse to accept overage children.

After a decade of neglect, several programmes fostered the resurrection of the rural infrastructure in hopes of reducing rural-urban migration. The threephase, World Bank-financed Sustainable Livelihoods Programme, launched in 2002, established community development funds. By 2013, before it entered its $3^{\text {rd }}$ phase in 2014, these funds had financed 6,000 subprojects. Among the activities, endeavors on education, health, and pasture management featured prominently. The current phase intends to bolster the Sum Programme ${ }^{20}$ and focus on capacity building for local governments. ${ }^{21}$ However, all social sectors-including education-are negatively affected by the extreme politicization of administration: after each election, most people in leading positions (including school directors) are replaced according to party affiliation. This highly controversial rotation of public positions (khalgaa selgee) jeopardises any successes in capacity building. To make matters worse, each election is preceded by an aura of paralysis and followed by haggling over positions; during each period, crucial decisions are suspended. Needless to say, this procedure, which has been widely criticised as a "political disease" (uls töriin övchin), contributes to a loss of popular trust in public institutions and administrative services.

\footnotetext{
19 Personal communication with teachers and parents at the nonformal education center Childrens' Ger in the period from 2003 to 2015.

20 The Sum Programme (Shine Sum Tösöl or Sumyn Töviin Shinechlel) was established in 2013.

21 http://www.worldbank.org/en/news/feature/2015/05/07/ providing-mongolias-rural-communities-with-sustainablelivelihoods
} 


\section{Epilogue}

As one of the ten richest countries in raw materials, "Minegolia" or "Moncoalia" is at the focus of transnational business interests. Environmental problems are as virulent as controversies over who should profit from the country's wealth. While rich elites seclude themselves in gated communities, one third of Mongolia's population is poor. Throughout the country, conflicts arise over land grabbing and the destruction of pasture land by mining. Herders engage in resistance movements to defend their pastoral livelihoods (Upton, 2012), and demand stricter enforcement of the so-called "law with the long name" (urt nertei khuul'), which prohibits mineral exploration and extraction near water sources, protected areas, and forests. ${ }^{22}$ Yet, unlike under socialism, herders (i.e. former arats now referred to as 'nomads') lack a positive collective identity. I agree with Dan Allman, who noted that, "just naming who is at risk of social exclusion, based on identity, vulnerability, membership, or biology will not suffice without some reflection as to who is naming the excluded, where those who label or define the excluded stand ontologically relative to their own or others' exclusion, and what if any the influences of personal, political, stereotypical, or xenophobic biases may be" (Allman, 2013, p. 9).

Mainstream educational thinking in today's Mongolia is founded on an urban, upper-middle class centrism. The government campaign, Zöv mongol khüükhed ündesnii khötölbör (right/correct/good Mongolian child national programme), launched in 2013, is an illustrative example. The campaign's stated intent is to foster creativity, self-confidence, decisiveness, lifelong learning, acquisition of the Mongolian language, culture, and customs in order to make proper citizens out of Mongolian children, a goal that is supposed to be reached through families, education and the social environment. ${ }^{23}$ The government and the Ministry of Education produced an official 5:07-minute video clip that shows the underlying value concepts. ${ }^{24}$ It starts with the sun rising over the steppe blended into Ulaanbaatar's main square, where boys in uniforms parade and salute in front of the government building and the national flag. Next, we see children and young people-partly dressed in national costumes-singing, waving, and presenting their talents and hobbies to friendly teachers who support them in and outside school. From 1:39-2:03, a girl and a boy are shown translating the song into sign language. This is the only part that demonstrates any kind of social inclusion. The video clip is shot entirely in the flawless urban settings of Ulaanbaatar's city centre. Only three extremely short, inserted sequences show rural children-two small boys

22 http://gal-undesten.blogspot.ca/2012/06/blog-post_387.html

${ }^{23} \mathrm{http}: / /$ www.news.mn/content/153784.shtml

${ }^{24}$ https://www.youtube.com/watch?v=8_ZhDLUVVEI holding kids $(1: 06-08 ; 2: 32-33 ; 4: 51-52)$. These sequences account for less than 5 seconds in a 5:07 minute video clip. Rural life appears twee; the image of children and youths holding kids has become iconic and features prominently on postcards, coffee-table books, and the latest Mongolia Human Development Report (2011). While the video clip cast are happy urbanites, socially deprived groups are clearly outcast. Strikingly, not a single ger $^{25}$ appears in the whole video clip, let alone a ger district that is home to two thirds of the capital's residents. Of course, middle-class centrism in education is rather the rule worldwide. Yet, from a government that takes pleasure in promoting Mongolia as a "land of nomads" (Myadar, 2011), and from elites who usually associate true Mongolian culture with the countryside (khödöö), one would expect a different and more inclusive representation of its younger generation.

\section{Acknowledgements}

I would like to thank two anonymous reviewers and the English editor for their comments and suggestions on an earlier version of this paper.

\section{Conflict of Interests}

The author declares no conflict of interests.

\section{References}

Allman, D. (2013). The sociology of social inclusion. Sage Open, 3(1), 1-16.

Appadurai, A. (1996). Modernity at large. Cultural dimensions of globalization. Minneapolis: University of Minnesota Press.

Avdai, C., Tömörjav, M., Songino, C., Dorj, B., Tsevegsüren, Z., \& Natsagdorj, N. (2003). Mongolyn nüüdelchdiin ündesnii ulamjlalt tekhnologi. Ulaanbaatar, Mongolia: UNESCO, NSISOUCh [International Institute for the Study of Nomadic Civilization], Shinjlekh Ukhaany Akademi.

Asian Development Bank. (2013). Education for the poor. Targeting strategies for the poor. Ulaanbaatar, Mongolia: Asian Development Bank.

Baasanjav, Z. (1999). Surgan khümüüjüülekh setgelgee, surguul', bolovsrol. In Mongol ulsyn tüükh (Tüükh onol-arga züin asuudluud) (pp. 321-326). Ulaanbaatar, Mongolia: Ulsyn Ikh Surguul \& Öchir Töv.

Batjargal, A. (1997). Bolovsrolyn salbart khiikh shinechleltiin yavtsad ankhaarakh zarim asuudluud. Bolovsrolyn Medeelel, 1, 41-45.

Bira, S. (1998/1999). Mongolyn nüüdliin irgenshil ba ulamjlalt medleg ukhaan. Bulletin. The IAMS News Information on Mongol Studies, 22(2)/23(1), 7-22.

\footnotetext{
${ }^{25}$ At present $45 \%$ of Mongolian households live in a ger ("Khün am", 2010).
} 
Bloch, A. (2003). Red ties and residential Schools: Indigenous Siberians in a Post-Soviet state. Philadelphia: University of Pennsylvania Press.

Bruun, O. (1996). The herding household: Economy and organization. In O. Bruun \& O. Odgaard (Eds.), Mongolia in transition: Old patterns, new challenges, (pp. 65-89), Richmond: Curzon.

Call for increased focus on education. (1997, August 20). The Mongol Messenger.

Chagdaa, C. S. (2002). Mongol malchny am'drakhuin ukhaan. Ulaanbaatar, Mongolia: “EV 2000" Khevleliin Gazar.

Chakrabarty, D. (2000). Provincializing Europe. Postcolonial thought and historical difference. Princeton, New Jersey: Princeton University Press.

Child, B. J. (1998). Boarding school seasons. American Indian families 1900-1940. Lincoln and London: University of Nebraska Press.

Chuluunbaatar, L. (2002). Nüüdelchin mongolchuudyn bichig üsgiin soyol. Ulaanbaatar, Mongolia: MUIS-iin Buddyn Soyol Sudalgaany Töv.

Clammer, J. (2003). Europe in Asia's imaginary. Disciplinary knowledges and the (mis)representation of cultures. In S. Lawson (Ed.), Europe and the Asia-Pacific. Culture, identity and representations of region (pp. 17-32). London and New York: RoutledgeCurzon.

Connell Szasz, M. (1999). Education and the American Indian. The road to self-determination since 1928. Albuquerque: University of New Mexico Press. (Original work published 1974).

Dash, M. (1966). Mongol orny bilcheeriin mal mallagaany arga turshlaga. Ulaanbaatar, Mongolia: UIsyn Khevlelijn Khereg Erkhlekh Khoroo.

Dorjgotov, N. (2002). Zarim ügiin tukhai. In International Institute for the Study of Nomadic Civilization (Ed.), Nüüdliin niigmiin olon ulsyn tüvshind sudlakh n'. Nomadism -International Study (p. 109). Ulaanbaatar, Mongolia: Nüüdliin Soyol Irgenshliig Sudlakh Olon UIsyn Khüreelen.

Dorzhsuren, Y. (1981). The flowering of art and culture. In The $60^{\text {th }}$ Anniversary of People's Mongolia (pp. 108-122). Ulaanbaatar, Mongolia, and Moscow: Unen Editorial Board and Novosti Press Agency Publishing House.

Düger, K. (1999). Bichig üseg medekhgüi 200 myangan zaluus bidnii dund baina. Zuuny Medee, 08.09(174), 3.

Dyer, C. (2001). Nomads and education for all: Education for development or domestication? Comparative Education, 37(3), 315-327.

Dyer, C., \& Choksi, A. (1998). Education is like wearing glasses: Nomad's views of literacy and empowerment. International Journal for Educational Development, 18(5), 405-413.

Enebish, J. (2002). Nüüdelchdiin baigal'-khögjim-khünii khariltsan shüteltsee. In International Institute for the Study of Nomadic Civilization (Ed.), Nüüdliin niigmiin olon ulsyn tüvshind sudlakh $n^{\prime}$. Nomadism-
International Study (pp. 130-134). Ulaanbaatar, Mongolia: Nüüdliin Soyol Irgenshliig Sudlakh Olon UIsyn Khüreelen.

Enebish, J. (2004). The nomadic roots of Mongolian music \& song. Mongol Survey, 13, 18-21.

Enkhtuvshin, B. (2002). Pressing problems of dialogue among civilizations and study of nomadic civilization in international and regional level. In International Institute for the Study of Nomadic Civilization (Ed.), Nüüdliin niigmiin olon ulsyn tüvshind sudlakh $n^{\prime}$. Nomadism-International Study (pp. 8-26). Ulaanbaatar, Mongolia: Nüüdliin Soyol Irgenshliig Sudlakh Olon Ulsyn Khüreelen.

Enkhtuvshin, B. (2004). New challenges for nomadic civilization and pastoral nomadism in Mongolia. Nomadic Studies, 9, 69-81. Ulaanbaatar, Mongolia: International Institute for the Study of Nomadic Civilization.

Enkhtuvshin, B., \& Tumurjav, M. (2001). Nomads and pasture use. In Open Symposium on "Change and Sustainability of Pastoral Land Use Systems in Temperate and Central Asia" (pp. 11-17). Ulaanbaatar, Mongolia: MAS/IISNC/LUTEA.

Escobar, A. (1997). The making and unmaking of the third world through development. In M. Rahnema \& V. Bawtree (Eds.), The post-development reader (pp. 85-93). London and New Jersey, Dhaka, Halifax, and Cape Town: Zed Books, University Press LDT, Fernwood Publishing and David Philip.

Fernández-Giménez, M. E., \& Huntsinger, L. (1999). Sustaining the steppes: A history of pastoral land use in Mongolia. The Geographical Review, 89(3), 315-342.

Finke, P. (2000). Changing property rights systems in Western Mongolia (Working Paper No. 3). Munich, Germany: Max Planck Institute.

Finke, P. (2004). Contemporary pastoralism in Central Asia. In G. Rasuly-Paleczek, \& J. Katschnig (Eds.), Central Asia on display. Proceedings of the VII. Conference of the European Society for Central Asian Studies (pp. 397-410). Vienna, Austria: Lit-Verlag.

Fratkin, E. (1997). Pastoralism: Governance and development issues. Annual Review of Anthropology, 26, 235-261.

Galaty, J. G., \& Johnson, D. L. (Eds.). (1990). The world of pastoralism. Herding systems in comparative perspective. New York: The Guilford Press.

Ganbaatar, J. (2001). Ikh nüüdliin tüükh. Ulaanbaatar, Mongolia: Mongol Ulsyn Ikh Surguul', Gadaad Khel, Soyolyn Surguul'.

Ginat, J., \& Khazanov, A. M. (Eds.). (1998). Changing Nomads in a changing world. Sussex: Academic Press.

Ginsburg, T. (1997). Mongolia in 1996: Fighting fire and ice. Asian Survey, 36(1), 60-64.

Giordano, C., \& Kostova, D. (2002). The social production of mistrust. In C. M. Hann (Ed.), Postsocialism. ideals, ideologies and practices in Asia (pp. 74-91). New York: Routledge.

Government of Mongolia. (2006). Masterplan to develop 
education in Mongolia. Ulaanbaatar, Mongolia: Government of Mongolia.

Gundsambuu, K. (2002). Social stratification in contemporary Mongolian society. Ulaanbaatar, Mongolia: "Zotol" Club of Professional Sociologists.

Humphrey, C., \& Sneath, D. (1999). The end of nomadism? Society, state and the environment of Inner Asia. Durham, UK: Duke University Press.

Innes-Brown, M. (2001). Democracy, education and reform in Mongolia: Transition to a new order. In M. Bray \& W. O. Lee (Eds.), Education and political transition: Themes and experiences in East Asia (pp. 7799). Hong Kong: Comparative Education Research Centre.

Kerven, C. (Ed.). (2003). Prospects for pastoralism in Kazakstan and Turkmenistan. From state farms to private flocks. New York: RoutledgeCurzon.

Khazanov, A. M. (1994). Nomads and the outside world. Madison: The University of Wisconsin Press. (Original work published 1984).

Khün am, oron suutsny 2010 ony ulsyn toollogyn ür dün. (2010). Retrieved from http://tuv.nso.mn/uploads/ users/4/files/XAOCT\%20uls.pdf

Krätli, S. (2000). Education provision to nomadic pastoralists. A literature review. Unpublished manuscript.

Lave, J., \& Wenger, E. (1991). Situated learning. Legitimate peripheral participation. Cambridge: University of Cambridge Press.

Leibold, J., \& Yangbin, C. (Eds.). (2014). Minority education in China. Balancing unity and diversity in an era of critical pluralism. Hong Kong: Hong Kong University Press.

Lkhagva, O. (2003). Ikh talyn nüüdelchdiin soyolyn undraga. Mongolica. An International Annual of Mongol Studies, 13(34), 92-103.

McGinn, N. F., \& Borden, A. M. (1995). Framing questions, constructing answers. Linking research with education policy for developing countries. Harvard: Harvard Institute for International Development.

Mearns, R. (1993a). Pastoral institutions, land tenure and land policy reform in post-socialist Mongolia (PALD Research Report 3). Sussex, UK: Policy Alternatives for Livestock Development in Mongolia.

Mearns, R. (1993b). Territoriality and land tenure among Mongolian pastoralists: Variation, continuity and change. Nomadic Peoples, 33, 73-104.

Ministry of Education, Culture and Science. (2015). Baga, dund bolovsrolyn statistik, 2014-15. Retrieved from http://www.meds.gov.mn/data/1503/BDB14-15.pdf

Mongol Ulsyn Zasgyn Gazar \& UNDP (1997). Mongol Khünii Khögjliin iltgel. Ulaanbaatar, Mongolia.

Munkhjargal, D. (1999). Mongolian national report on Education for All assessment-2000. Ulaanbaatar, Mongolia: Ministry of Science, Technology, Education and Culture, UNDP, UNESCO, UNICEF, UNFPA, World Bank.

Monkhor, D., \& Damdinsüren, B. (1998). Bolovsrolyn khögjliin talaarkh sudalgaag chukhalchil'ya. Bolovsrol Medeelel (Education \& Information), 7(11), 47-54.

Moock, P. R., \& Namsraidorj, B. (2013). Suggestions for revisions of the per student funding formula for general secondary education in Mongolia. In Education for the poor. Targeting strategies for the poor (pp. 657). Ulaanbaatar, Mongolia: Asian Development Bank.

Myadar, O. (2011). Imaginary nomads: Deconstructing the representation of Mongolia as a land of nomads. Inner Asia, 13(2), 335-362.

Namkhainyambuu, T. (2000). Bounty from the sheep. Autobiography of a herdsman. Cambridge: The White Horse Press.

Natsagdorj, S. (1967). The economic basis of feudalism in Mongolia. Modern Asian Studies, 1(3), 265-281.

Ontsgoi tomilolt. (2011). Ulaanbaatar, Mongolia: Mongol Ulsyn Batlan Khamgaalakh Yaam.

Postiglione, G., Jiao, B., Xiaoliang, L., \& Tsamla. (2014). Popularizing basic education in Tibet's nomadic regions. In J. Leibold \& C. Yangbin (Eds.), Minority education in China. Balancing unity and diversity in an era of critical pluralism (pp. 107-129). Hong Kong: Hong Kong University Press.

Rinchen, B. (1964). Mongol bichgiin khelnii züi. Tergüün devter. Ulaanbaatar, Mongolia: Shinjlekh Ukhaany Akademiin khevlekh üildver.

Samoff, J. (1999). Education sector analysis in Africa: Limited national control and even less national ownership. International Journal of Educational Development,19(4/5), 249-272.

Sandshaasüren, R., \& Shernossek, I. (1981). Das Bildungswesen der Mongolischen Volksrepublik. Beiträge zur Pädagogik. Berlin: Volk und Wissen.

Sanzhasuren, R. (1981). The torch of knowledge. In The $60^{\text {th }}$ Anniversary of People's Mongolia (pp. 89-91). Ulaanbaatar, Mongolia, and Moscow: Unen Editorial Board and Novosti Press Agency Publishing House.

Schmidt, S. (1995). Mongolia in transition. The impact of privatization on rural life (Bielefelder Studien zur Entwicklungssoziologie Vol. 62). Saarbrücken: Verlag für Entwicklungspolitik.

Shagdar, S. (2000). Mongol ulsyn bolovsrolyn tovchoon. Ulaanbaatar, Mongolia.

Shagdarsüren, O. (1969). Baigalyn shalgaral ba belcheeriin mal aj akhui. Ulaanbaatar, Mongolia.

Shagdarsüren, L. (1976). BNMAU-yn yerönkhii bolovsrolyn khödölmör politekhnik surguuliin üüsel, khögjilt. Ulaanbaatar: Ardyn Bolovsrolyn Yaamny Khevlel.

Sneath, D. (1996). Combining ecological and social studies in the contemporary study of pastoralism in Inner Asia. In V. A. Koptyug \& M. Uppenbrink (Eds.), Sustainable development of the Lake Baikal region. A model territory for the world (pp. 265-284). Berlin: Springer.

Sneath, D. (1999). Mobility, technology, and decollectivization of pastoralism in Mongolia. In S. Kotkin \& B. A. Elleman (Eds.), Mongolia in the twentieth century. 
Landlocked cosmopolitan (pp. 223-236). Armonk, USA: M.E. Sharpe.

Sneath, D. (2000). Producer groups and the decollectivisation of the Mongolian pastoral economy. In. J. Heyer, F. Stewart, \& R. Thorp (Eds.), Group behaviour and development. Oxford: Oxford University Press.

Sneath, D. (2002). Mongolia in the 'age of the market': Pastoral land-use and the development discourse. In R. Mandel \& C. Humphrey (Eds.), Markets and moralities. Ethnographies of postsocialism (pp. 191-210). Oxford: Berg.

Sneath, D. (2003). Lost in the post: Technologies of imagination, and the Soviet legacy in post-socialist Mongolia. Inner Asia, 5, 39-52.

Solga, H. (2014). Education, economic inequality and the promises of the social investment state. Socio Economic Review, 12, 18-25.

Steiner-Khamsi, G., Stolpe, I., \& Tümendelger, S. (2003). Bolovsrolyn tölöökh nüüdel. Shine Toli, 45(4), 82-112.

Steiner-Khamsi, G., Stolpe, I. (2006): Educational import: Local encounters with global forces in Mongolia. New York: Palgrave Macmillan.

Stolpe, I. (2008). Schule versus Nomadismus? Interdependenzen von Bildung und Migration in der modernen Mongolei. Frankfurt, Germany: Peter Lang.

Stolpe, I. (2010). Earthing eternal heaven: Towards a mongolization of educational philosophies. Mongolian Studies, XXXII, 1-32.

Stolpe, I. (2011). Zud in der Mongolei: Perspektiven auf wiederkehrende endemische Katastrophen. Mongolische Notizen, 19, 44-60.

Stolpe, I. (2015). Truly nomadic? Die Mongolei im Wandel. $A P u Z, 26 / 27,25-31$.

Sükhee, S. (1988). Mongol ardyn surgan khümüüjüülekh züin ulamjlal, devshliin zarim asuudal. Ulaanbaatar, Mongolia: Ulsyn Khevleliin Gazar.

Sum'yaa, B. (2005). Mongolyn nüüdelchdiin soyol. Ulaanbaatar, Mongolia: International Institute for the Study of Nomadic Civilization.

Szynkiewicz, S. (1998). Contemporary concepts of being pastoralist: institutional continuity, change and substitutes. In J. Ginat \& A. M. Khazanov (Eds.), Changing nomads in a changing world (pp. 202-222). Sussex: Academic Press.

Tatto, M. T. (1999). Education reform and state power in
Mexico: The paradoxes of decentralisation. Comparative Education Review, 43(3), 253-278.

Taube, M. (2005). Die Geheime Geschichte der Mongolen: Herkunft, Leben und Aufstieg Dschingis Khans. Munich: Verlag C.H. Beck.

Tavakolian, B. (2003). Multiplicities of nomadism and varieties of anthropological theory. Reviews in Anthropology, 32, 297-314.

Tömörjav, M. (1989). Belcheeriin Mongol Mal. (Ashig, shim, biologiin gol chanar). Ulaanbaatar, Mongolia: Ulsyn Khevleliin Gazar.

Tömörjav, M. (2002). Töv Aziin nüüdellekhüi yoson, tüünd garch bui öörchlöölt: Surgamj, dügnelt. In International Institute for the Study of Nomadic Civilization (Ed.), Nüüdliin niigmiin olon ulsyn tüvshind sudlakh $n^{\prime}$. Nomadism-International Study (pp. 38-44). Ulaanbaatar, Mongolia: Nüüdliin Soyol Irgenshliig Sudlakh Olon Ulsyn Khüreelen.

Tsanjid, A. (2005). Mongol soyol irgenshil. Ulaanbaatar, Mongolia: Mönkhiin Üseg.

UNESCO. (1993). World education report. Paris: UNESCO.

UNESCO. (2011). World data on education. Mongolia (7th ed.). Geneva: International Bureau of Education.

United Nations Development Programme, \& Government of Mongolia. (2011). Mongolia human development report. Ulaanbaatar, Mongolia: Government of Mongolia, UNDP, SIDA.

United Nations Development Programme in Mongolia. (2014). Sustainable urban development in Mongolia. UNDP in Mongolia. Retrieved from http://www.mn.un dp.org/content/mongolia/en/home/presscenter/deve lopment-dialogues-/DevelopmentDialogue8.html

Upton, C. (2012). Mining, resistance and pastoral livelihoods in contemporary Mongolia. In J. Dierkes (Ed.), Change in democratic Mongolia: Social relations, health, mobile pastoralism, and mining (pp. 224248). Leiden: Brill Press.

World Bank. (2002). Public expenditure and financial management review. Bridging the public expenditure management gap. Washington: World Bank.

Yembuu, B. (2008). National report on the situation of Adult Learning and Education (ALE) Mongolia. Ulaanbaatar: National Centre for Non Formal and Distance Education, Ministry of Education, Culture and Science.

\section{About the Author}

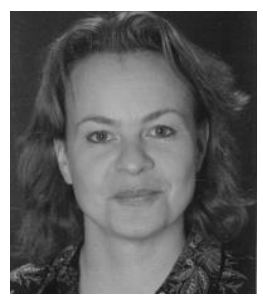

\section{Dr. Ines Stolpe}

After graduating in Mongolian Studies and Education in Berlin and Ulaanbaatar, Ines Stolpe obtained her PhD in Central Asian Studies from Humboldt-University Berlin on the interdependencies of social and spatial mobility in contemporary Mongolia. Since 2013, she has been professor for Mongolian Studies at the Department of Tibetan and Mongolian Studies at the University of Bonn. Her research interests and areas of teaching include Mongolian language, cultural and political history and social change, educational philosophy, civil society, and Post-Socialist studies. 